\title{
Negotiating Spaces of Exception
}

\author{
Metro Manila's Planned Unit Developments: The Case of \\ Eastwood City
}

Anna Katrina KARAAN; Philippines

\begin{abstract}
Urban enclaves have come to define the growth of many contemporary cities, subdividing society spatially into homogenous groupings. In the global south, this has been translated even more distinctly due to the excessive disparity among social classes. With their predisposition towards exclusion, urban enclaves are often portrayed as particular sites of unsustainability. However, a specific version of these enclaves, the Planned Unit Development (PUD) and its current manifestation of high-density mixed-use townships, has been championed as a concept that inculcates more sustainable practices due to its innate flexibility. Utilizing a localized actor-centric approach, this study uncovers how PUDs in Metro Manila are negotiated as spaces of exception. The study uses a representative case study of one of the pioneering PUDs in Metro Manila, Eastwood City, and applies a qualitative methodology to explore how relations of state-space-society creates and continuously shapes these spaces. Eastwood City is uncovered to be a legitimized space of exception, where dominant narratives have prioritized private over public interests, but crossed into the realm of acceptability due to its claims of sustainability, particularly of the "live-work-play" lifestyle. However, this study also reveals how the narratives of the dispossessed are exhibited in the margins and how this is continuously (re)shaping the development. These point towards the possibility of alternative futures for PUDs by shifting the power to negotiate to all stakeholders, not only in the creation but also throughout the lifespan of the project, which can then lead to more inclusiveness and equality in the process. By operationalizing the PUD concept, urban enclaves can cease to be purveyors of singular interests but become dynamic spaces of exception that are constantly negotiated by their actors.
\end{abstract}

\section{Keywords}

Urban enclaves, planning tools, zoning exemptions (3-5)

\section{Introduction}

Narratives of urban development around the world have seemingly taken similar storylines. Cities have bought into the neoliberal ideology of privatization and competition, manifesting into the formation of enclaves that subdivide society into homogeneous groupings (Agnotti, 2013). In the global south, this phenomenon has been translated even more distinctly due to the excessive disparity among different societal classes, leading to further inequality through exclusion. This is a story that is exceedingly evident in Metro Manila, the capital region of the Philippines (Murphy \& Hogan, 2012). 
A rapidly urbanizing megacity, Metropolitan Manila is an agglomeration of seventeen municipalities that politically subdivide a contiguous urban area. These local government units (LGUs), despite sharing a functional area, remain highly disparate with their own policies and agendas (Porio, 2009). While the political scenario is weak, powerful elites have been shaping Metro Manila's urban fabric in the form of urban enclaves to fill in the gap (Shatkin, 2008: 388). These developments, usually targeted to the middle and upper classes, present a common model of the privatization of space (Roderos, 2013: 99).

Recently, a unique type of enclave development in Metro Manila has arisen. Planned Unit Developments (PUDs) in the form of urban townships are driving much of the national capital region's urban (re)development, where large areas of land are purchased and converted into high-density mixed-use developments by the private sector (Aquino, 2015). However, the nature of these types of enclaves contradict existing regulations and can only exist as an exception, facilitated by LGUs that desire this type of development in their city.

This particular type of enclave opens discourses on their existence as spaces of exception that are negotiated through power/knowledge relations among various actors. By taking Eastwood City as an exemplary case, the study is able to examine one of the pioneering urban townships in Metro Manila using a qualitative methodology to uncover the processes that underlie how these are being shaped.

\section{Literature Review}

\subsection{Enclave Urbanism}

Due to their prevalence, urban enclaves have spawned numerous studies (see Agnotti, 2013; MacLeod \& Ward, 2002; Sidaway, 2007; Genis, 2007), often focusing on the way these are shaped by the rise of neoliberal ideology, which "mobilises urban space as an arena for market-oriented economic growth and elite consumption practices" (Sager, 2011: 149). A common manifestation of these is the mono-use gated community. These typically enclose a homogeneous class of people who can afford to pay for reliable services and security that, in many cases, only the private sector can provide (Grant \& Mittelsteadt, 2004). In developing countries, these communities provide a sense of separation from the poverty prevalent in the city (Webster et al., 2002: 317).

Enclaves, however, are not only defined through the physical gating but also exist in spaces "that are presumed as part of an open city" (Agnotti, 2013: 115). They have co-opted urban movements that aim to provide more sustainable urbanity than what is present in modern cities through the creation of mixed-use communities, such as new urbanism (Council for New Urbanism, 2015), urban villages (Franklin \& Tait, 2002), and compact cities (Hofstad, 2012). While these spaces ideally create sustainable communities and have become ideal city models (Jensen et al., 2011), reality reveals that these promulgate other unsustainable practices through exclusion instead (Jenks \& Jones, 2010).

Recent studies on enclaves have shifted beyond dystopic representations of the city based on "overextended neoliberalism" into more nuanced approaches that explore localized manifestations (Pow, 2015), placing more importance on specific political, economic and social processes (McGuirk \& Downling, 2009; Johnson, 2010; Koch, 2015). While not discounting neoliberalism as a driving force, the discussions emphasize enclaves as locally produced spaces that be seen as decision-making moments. Arranged urbanism evaluates 
the interactions of state and non-state actors in the creation of space, and showing the close interaction of formal and informal practices in these enclaves (Koch, 2015: 409). The concept of borderland urbanism shifts from how enclaves are formed to how they are constantly changing at its boundaries through "continuous negotiations of power and control" and "continuously changing and evolving relational linkages" (lossifova, 2015: 104). These borderlands become sites for alternative ways of being that challenge the static definition of enclaves (ibid.).

A similar thread among these concepts is the aim to redefine these spaces through processes of negotiation among different actors. However, as inequality is present and normalised as an intrinsic part of contemporary urbanism (MacLeod et al., 2003: 1667), negotiations tend to favour those who possess power while the bargaining of the powerless occurs at the margins. Refocusing on these interactions allows for enclaves to be seen not just as results of a global neoliberal process but as dynamic spaces that are continuously being shaped by localized relations.

\subsection{Metro Manila's Urban Enclaves}

The issue of enclave-ing is clearly prevalent in Metro Manila, a city that has been referred to as "the world's most fragmented, privatized, and un-public of cities" (Murphy \& Hogan, 2012: 27). While this may be a hyperbolic statement, urban space in Metro Manila have been subdivided into private spheres to such a degree that "everyone except the utterly dispossessed ... erects gates and fences and walls around their property and themselves" (ibid., 2012: 12). Enclaves in Metro Manila are not only the realm of the elite but are used by all classes to segregate themselves from one another (Garrido, 2013: 1343). With this kind of urbansim, the notion of public space has been relegated to quasi-public spaces within the private.

Neoliberalism has indeed spurred the formation of enclaves in the capital region with imaginaries of a sanitized "global city" through private-sector led mega-projects (Shatkin, 2006; Connell, 1999; Michel, 2010; Kleibert \& Kippers, 2015). These are informed by a strong postcolonial identity that produces these "visions of a world class and modern metropolis" (Ortega, 2016: 35) with a "cultural distinction on the basis of progress" that has been internalized by the citizens (Garrido, 2012: 182). Moreover, these are facilitated by a highly patrimonial society, which places the power to plan in the hands of influential landed families (or those with ability to accumulate land), "[creating] what is in effect an urban feudalism ... [building] their own 'manorial' cities within Metro Manila" (Murphy \& Hogan, 2012: 23).

It appears that the government has conceded much ground to these private actors due to "intense fiscal and external pressures ... and a local political economy that has fostered the political power of elite families" (Shatkin, 2008: 398), and has facilitated the dominance of private sector-led planning in the development of Metro Manila through the creation of "for-profit utopias" (ibid.: 399). With the diminished role of the public sector, uneven development and social divisions through the creation of exclusive spaces have become the common mode of urbanisation, often leading to the dispossession or displacement of the poorer members of society (Choi, 2014; Ortega, 2016; Roderos, 2013). However, while these descriptions present an overly powerful private sector, these developments can also be seen as a means to fulfill national or local agendas, which may mark them worthy of state facilitation (Kelly, 2003). 


\subsection{Planning for Exemptions}

The congruence of factors involved in the urbanisation of Metro Manila has led to the popularization of a particular manifestation of urban enclaves: the Planned Unit Development (PUD), a planning concept and tool that originated from the United States of America in the 1950s and 60s (Burchell, 1973: 3). PUDs began as a reaction to the Euclidean zoning system that separated land uses and enforced uniform regulations. This system was criticised for being highly unsustainable as it encourages urban sprawl, perpetuates homogenous communities, prevents the development of useable open spaces, and discourages innovations in land use or design. The PUD concept answers these critiques as it allows for a more integrated form of development, and has since become increasingly popular (Mandelker, 2008: 420).

However, PUDs require more flexibility of uses than what the current system sanctions, which necessitate exceptions from zoning and other regulations as these "[do] not employ pre-set regulation but rather emphasizes land conversion through the art of negotiation" (Burchell, 1973: iii). This discretionary nature of PUDs has been seen as both a solution and a problem. While it provides flexibility that could enhance quality of life and form more sustainable communities, issues arise in the processes of negotiation, regulation, and the subsequent implementation of these in the urban space, as PUDs left unchecked often become exceedingly geared toward private interest (Committee on Public Regulation of Land Use, 1972: 62-64). Although controlling PUDs is said to defeat its purpose, recommendation on how to tackle these developments have been brought forward (Burchell, 1973; So, et al., 1973; Meshenberg, 1976), and some of these remain relevant: a sound policy base, a range of allowable discretions, submitting a plan for review, and collaboration with experts (Meshenberg, 1976: 2).

Planning tools that aim for increased flexibility in land use are not unique to the PUD, and can also be found in other countries with varying degrees of success. While these are known by different names and follow different processes, they ultimately have similar intentions shifting from comprehensive plans to projects allowable through public concessions (Mosciaro and Pereria, 2019). Two prominent examples are the French zone d'aménagement conserté (ZAC) and the Brazilian Operação Urbana (Urban Operation - UO). Unlike the PUD, these are characterized more by the heightened role of the public sector, with the developments considered a public-private partnership, than a primarily private initiative.

The ZAC is a widespread instrument for implementing development schemes in France. Under the authority of the local government (though often initiated by interest private investors), designated areas for comprehensive redevelopment are granted special planning regime (plan d'aménagement de zone or $\mathrm{PAZ}$ ), and revenues from land sales/leases and concessions granted by the ZAC is intended to fund the infrastructure of the development. While initially intentioned for new large-scale urban projects, it is also used in smaller development projects which facilitates complete private-sector funding, or projects in existing urban districts, which necessitates tighter control favoring rehabilitation over demolition (EC, 2000). In any case, even with the presence of private sector partners, the public sector still holds principal control over the development. This is attributed to the historical institutional culture of France that promotes collaborative processes, which extends to the inclusion of other interest groups and undergoes a public participation processes. For instance, in the ZAC Bercy in Paris, private sector partners were not given 
preference treatment over environmental considerations (Nelson, 2000). However, the number of actors involved has made the process long and complex, and the control of the local authorities are oftentimes seen as restrictive.

Similarly, the Brazilian Urban Operations (UOs) aims to become a vehicle for joint efforts among public and private sectors in urban projects. UOs are enacted in law by the local government and "addresses issues such as the perimeter of the intervention, the zoning and building rules applied inside it, the aggregate stock of development rights, the conditions for negotiating these rights, the general guidelines for infrastructure improvements, and the basic governance framework to manage the project" (Moscario and Pereira, 2019: 4-5). One main mechanism is its use of additional development rights within the UO perimeter to finance improvements. These development rights (CEPACs) allow developers to exceed the standard floor-area ratio (FAR) permitted in UO, up until the maximum allowable FAR, increasing the flexibility of the use of space. While UOs are promulgating within Brazil and often seen as a best practice, it has been critiqued as further increasing uneven development due to the prevalence of market-interest over social-interest typical in these types of enclaves (Moscario and Pereira, 2019).

In the Philippines, where land use zoning and building codes are closely patterned after the US zoning system, the concept of PUD has been vaguely defined at the national scale, and enclaves that follow this definition are quickly becoming a main form of urban (re)development. Urban townships, which are privately owned and managed, often highdensity, mixed-use "compact" developments, is emerging as the prevailing type of PUD (Kleibert \& Kippers, 2013). However, while the intention may be similar to the developments described from the cases of France and Brazil, unlike in those countries, there is little evidence of regulatory measures or practices operationalising these developments in most cities in the Philippines, implying a scenario where PUDs exist as exceptions facilitated primarily through discretionary bases.

\subsection{Defining Spaces of Exception}

Throughout the literature reviewed, shifting discourses and practices on urban enclaves and their enabling planning frameworks considers spaces as "defined less by a pre-given property and more by the assemblages they enter and reconstitute" (McFarlane, 2011: 208). However, because enclaves are often sites of inequality, difference in power affects the ability of actors to negotiate in decision-making processes. According to Foucault, power is in flux and is constantly negotiated through the reinforcement or redefinition of knowledge or "truths" that are legitimized through various means (Mills, 2003: 33).

A prevailing discourse is the role of states of exception where suspension of norms creates opportunities for decision-making, and at the same time, the legitimacy of the decision maintains this exception as within order (Agamben, 2005). This is facilitated through the blurring binary between formal/informal (Roy, 2005), and further explained by Yiftachel as "gray spaces", which are either "whitened" if deemed beneficial to those in power, or "blackened", if not (Yiftachel, 2009: 243). This challenges the notion of exceptions being a static categorization; instead, as a practice, (in)formality has an active involvement in the production of space and its legitimacy (McFarlane, 2012: 105).

This argument presents space as dynamic and constantly negotiated through practices of (in)formality, and allow for places that can be highly adaptable to the ever-changing local and global contexts (Herrle \& Fokdal, 2011: 12). PUDs, whose very nature depends on 
flexibility, can be offered as examples of space of exception. Metro Manila, where PUDs are defining much of the urban (re)development yet is not regulated in the planning system, is an ideal context to explore how assemblages embody power/knowledge relations and is used to negotiate spaces of exception.

\section{The Case of Eastwood City}

The study on Eastwood City aims to uncover the processes that underlie negotiating Planned Unit Developments in Metro Manila, specifically the private developer-led urban township, using a representative case study approach by qualitatively analysing how these occur in the assemblage of state (particularly local and sub-local/barangay ${ }^{1}$ levels), society, and space. The perspectives of both state and society were gleaned through a series of interviews and further supported by documentary analysis of various regulatory plans, guidelines, ordinances and marketing materials. Space was assessed based on how state and society perceive and interact with it, and further supplemented by site observation and mapping. Following this, the results were analysed through the description of how Eastwood City was created, and by placing the PUD within the discourses of power, in order to examine how this space of exception was and continues to be negotiated.

\subsection{Creating a Space of Exception}

Eastwood City widely promotes its exceptional-ism: the first integrated township that first delivered the live-work-play lifestyle concept through incorporating the first Cyberpark in the country targeting the emerging service industry of Business Process Outsourcing (BPO). Its very selling point was that it did not conform but set itself apart through its difference. Even now, years later and succeeded by numerous copycat developments, it still claims this difference by repeatedly highlighting that it was the first-the original.

This exceptional-ism is not only present in its marketing campaign. Its existence began through seeking exemptions from current zoning plans. The area where Eastwood City now stands was originally an industrial zone occupied by factories and warehouses, except for an existing low-income/working class community that classified as a socialized housing zone ${ }^{3}$, referred simply as Barangay Bagumbayan. Opportunely, the industrial area ran adjacent to a major highway (C-5) that links the north to the south of Metro Manila, and surrounded by large swathes of residential areas. This generated sufficient traffic and high market catchment, making the area appealing for commercial developments.

In 1996, Empire East Holdings (now known as Megaworld Corporation) was able to purchase some contiguous industrial lots in the area to create a mixed-use Planned Unit Development. While no formalized planning mechanism are in place to operationalise PUDs in the local level, these developments still persist through co-opting existing processes, beginning with the request for a change of zoning from industrial to Special (Urban) Development Zone under the QC Zoning Ordinance of 1992, reserved as "areas characterized by deteriorated or deteriorating conditions but with high potential for environmental rehabilitation and socio-

\footnotetext{
1 "The basic political unit [in the Philippines] which serves as the primary planning and implementing unit of government ... activities in the community" (Endriga, 2004).

${ }^{3}$ A socialized housing zone is an area assigned primarily for housing of the underprivileged or homeless (Endriga, 2004).
} 
economic improvement" (QC Ordinance No. SP-1369, S-2003). Once zoned as SUDZ, more flexibility is granted in the uses the lot can exhibit. Eastwood City was presented to fit this definition through the argument that "the subject site being in the growth corridor of C-5 is strategically located and highly accessible, thus presenting itself as another potential growth center for Quezon City" (QC Ordinance No. SP-432, S-96).

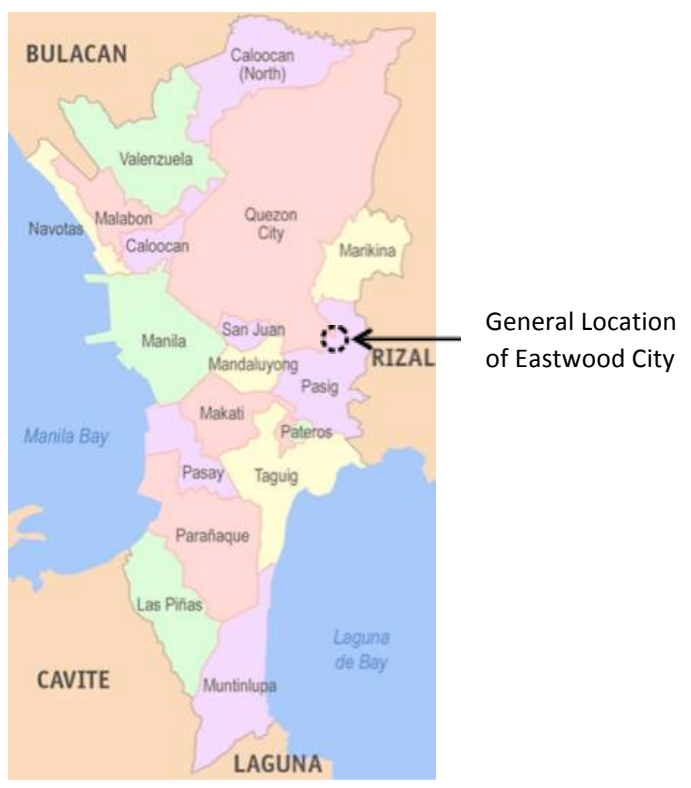

Figure 1 Political map of Metro Manila (with Eastwood City), source: Philippine Maps

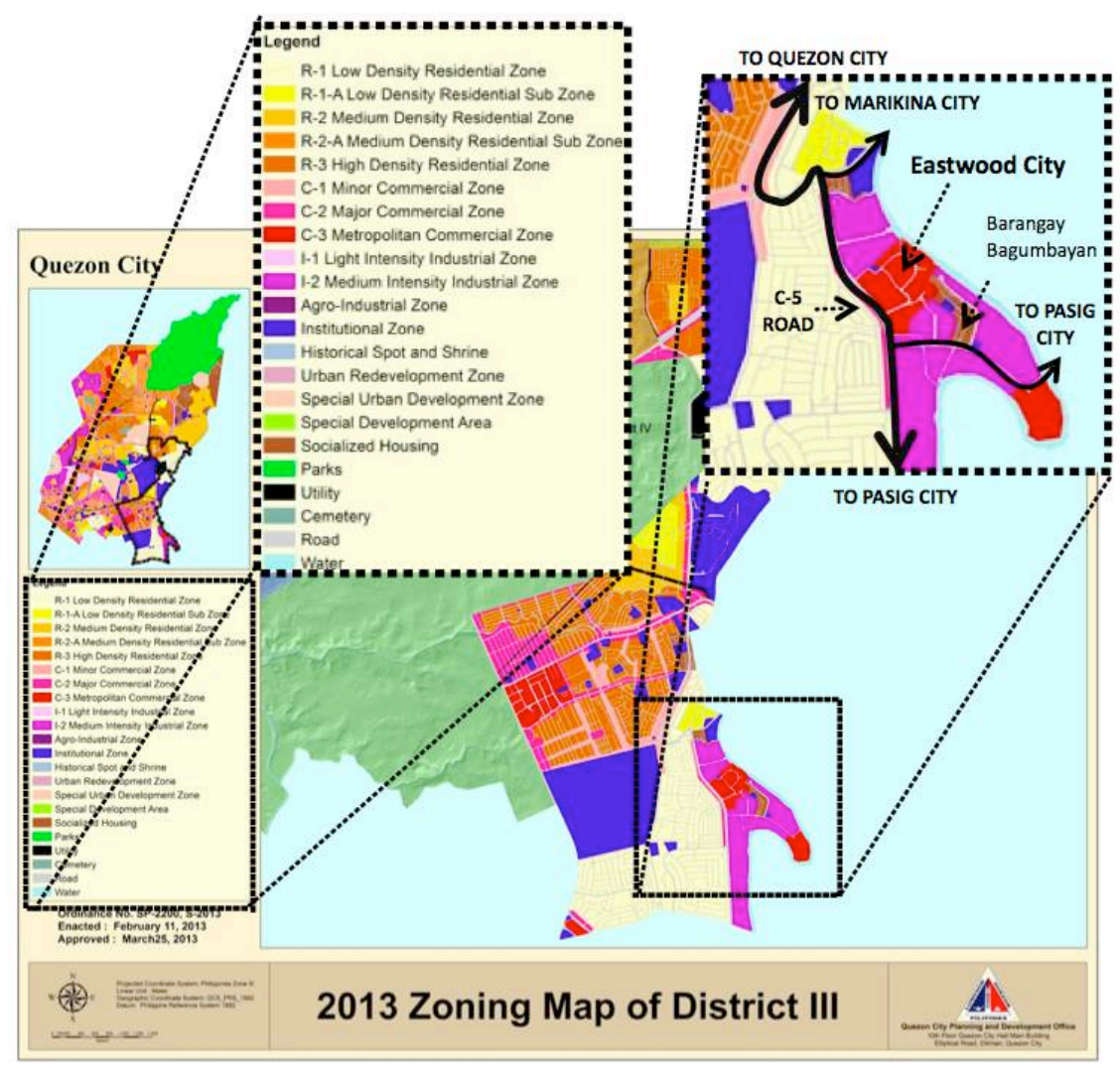

Figure 2 Quezon City 2013 Zoning Map of District III (with insets), source of base map: Local Government of Quezon City 
The reasoning of being a growth centre was appealing. The highly residential nature of Quezon City has spurred its local government to encourage diversification of land uses that could lead to increased economic opportunities (Quezon City Development Council, 2010). With this, Eastwood City was granted uses allowable in a Metropolitan Commercial Zone (C3) (Quezon City Ordinance No. SP-432, S-96), which has the least restrictions: no height limit, generous floor-to-lot area ratio (FAR) allowances, and the ability to mix uses in one development. However, this also means that in terms of planning the development, there is barely any input from the city's planning department, whose statement was "we don't know what's happening inside Eastwood; only Megaworld knows that." (Interview, 17 July 2016)

In order to be rezoned, the developer needed to make a request to the City Council, which has the sole power to enact and revise zoning ordinances. While the national agency Housing and Land Use Regulatory Board (HLURB) has prescribed guidelines on when and how zoning exceptions should be allowed in order to limit adverse effects of zone changes, it appears that the council has procedures of its own. While a high-density commercial development in the midst of a low-density industrial and residential area can most definitely be foreseen as causing adverse effects, the zoning exception was approved without limitations, enabling the developer to proceed with the kind of development that would best maximize its profits.

This process of exceptions clearly shows a mutually beneficial transactional relationship between the local government and the developer. For the developer, the benefit is that the desired development was approved at all and with few restrictions, allowing them to economize space and maximize profit. For the local government, the benefits are multifaceted. Vehicles of economic growth such as these high-density developments are seen as desirable additions to the city. These developments provide higher tax and other revenues to the city and its officials, as well as services to the citizens that the local government is incapable of providing (Porio, 2012: 7).

This sentiment persists not only in Quezon City but in other cities of Metro Manila as well. The strong presence of private investments underlies much of the progress in terms of services and infrastructure issued by the local governments (Shatkin, 2006: 593). Due the competitive atmosphere present and a lack of metropolitan governance, there is a race among these LGUs to attract these investments to their cities. Oftentimes, the winning strategy of the LGUs is their willingness to give concessions, from allowing much higher densities than what is advisable to sacrificing required spaces for amenities to benefit the private developer (Land Use Expert, interview, 27 July 2016).

In this scenario, power is constantly shifting through various levels of informal negotiations. On one side, the state wields land policies as an important bargaining tool; on the other, the developer presents desirable resources. The general public, however, plays little role in these initial negotiations that generally occurs behind closed doors. Thus, while the system does not follow what is officially prescribed, the rules of the game are known by their players who use this knowledge to put forward their own agendas. It is not an unregulated system, as usually follows the common notion of informality, but a deregulated one. As Roy (2009) states, "[deregulation] indicates a calculated informality, one that involves purposive action and planning, and one where the seeming withdrawal of regulatory power creates a 
logic of resource allocation, accumulation, and authority" (2009: 83). Through deregulated systems, it is possible for (in)formally negotiated decision-making to take place.

\section{2. "Whitening" the Grey}

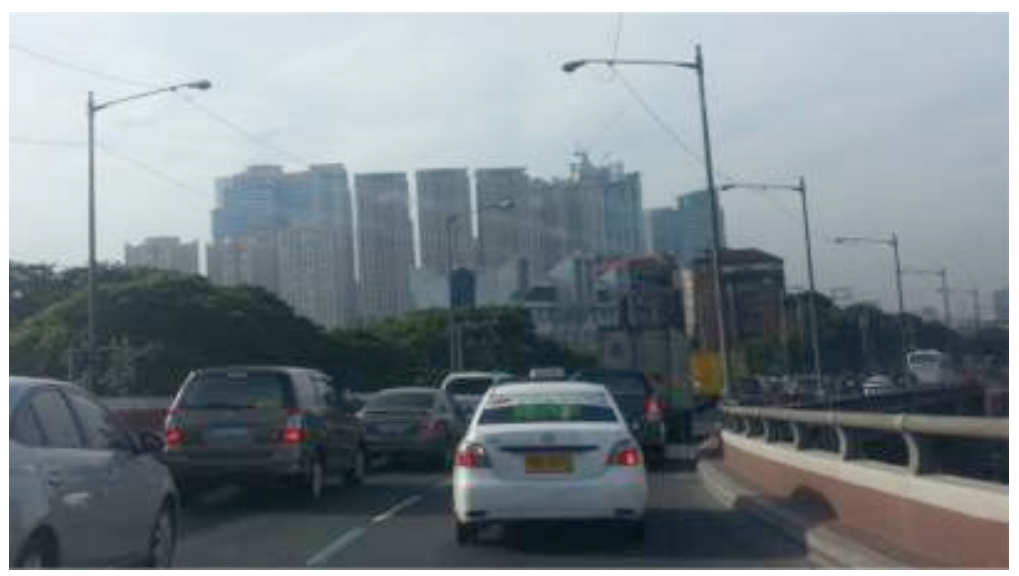

Figure 3 View of Eastwood City from C-5 Road, source: author, July 2016

Though not playing an active role in its creation, a general sense of satisfaction with the development is echoed by those interviewed, including those who would seem typically excluded from these types of development such as the working class population and residents of the adjacent poorer community (Roderos, 2013). For them, Eastwood City delivers a unique type of urban space that suitably answers their needs. This sentiment reveals that Eastwood City is a gray space that has been "whitened" (Yiftachel, 2009: 243). Instead of being seen as unacceptable, the PUD has been legitimised through the shared power/knowledge of the state and developer that capitalises on certain narratives.

While it should be noted that these are not representative of all stakeholders of the PUD, not one interview failed to mention the convenience that Eastwood City has brought to them. The location of this development places it as the easternmost commercial and business district in Metro Manila and close to the vast residential areas characterizing the eastern portion of the capital region, bringing employment opportunities and commerce/recreational areas closer to where many people reside. In addition, it hosts the Business Process Outsourcing (BPO) industry, which has been responsible for much of the country's economic growth in the past several years (estimated at 7.3\% of GDP and 1.3 million jobs for 2016) and has allowed many working class Filipinos to improve their economic standing (Oxford Business Group, 2015).

Locating a business centre in Eastwood City has not only supported the direct users of the development, but also those who live nearby. For the residents of Barangay Bagumbayan, the low-income community adjacent to the PUD, having Eastwood City as a neighbour enabled new forms of income-generation through means such as room rentals and food sales that serve as low-cost alternatives to options inside the PUD. These accounts show that there has been an improved access to opportunities for a diverse group of people. This decentralisation of economic activity was indeed the claimed aim when Quezon City allowed for the reclassification of the industrial lot, and the development seems to have delivered on this. This has particularly strengthened its legitimacy in the eyes of various stakeholders, emphasizing the PUD's "whiteness". 
Moreover, its main selling point, creating a live-work-play lifestyle, is particularly attractive not only to its users. Compact developments, touted as the anti-thesis to the unsustainable urban sprawl, aims to deliver a more sustainable lifestyle through dense mixed-use communities and has been promoted by the international community as a model of urban development (Jensen et al., 2011). The main advantages include more efficient services and shorter travel times leading to improved quality of life, less reliance on private vehicles that subsequently lessens consumption and pollution, and availability of diversity of opportunities, all of which lead to a better urban environment (Hofstad, 2012).

The compact city and similar developments, however, have been challenged as fallacious when its concept is translated into reality. Instead of being an instrument of sustainability, it becomes "a static product of developer's marketing campaign rather than an evolving process of human development" leading to inauthentic communities (Neuman, 2005: 22) and is implemented through "cherry-picking those aspects of the compact city as a sustainable urban model most attractive to their needs, such as increasing densities... which largely reflect dominant economic or environmental interests" (Dempsey \& Jenks, 2010: 119). This densification tends to lead to further degradation of the environment, as it increases congestion, pollution and lack of open space. Furthermore, because social issues are not central to the concept, these developments tend to exclude those who cannot afford to pay for the lifestyle (Smyth, 2005: 92). Thus, compact developments tend to be exclusive spaces that favour the affluent, and encounters issues such as gentrification and displacement.

These critiques against compact developments are highly evident in Eastwood City, such as traffic congestion, open space deficit, and overloaded utility services. Rising concern about the development's vulnerability to disasters also gripped many of those interviewed because, coupled with the dubious quality of the buildings, Eastwood City is located next to often flooded Marikina River and the West Valley Fault Line. These emphasize that Eastwood City's claim to offering a "good life" may not be entirely valid. Arguments of sustainability focus mainly on economic aspects, while social and environmental aspects remain secondary, leading to very real concerns about the impacts of the development in the urban area.

Recently, doubts about the development have been increasing due to these issues, prompting the new Comprehensive Land Use Plan (CLUP) of Quezon City to remove its status as a growth centre due to these "built-in site limitations" (Quezon City Development Council, 2010: 22), but this has not yet been enacted and Eastwood City continues to grow. However, while these factors lessen the legitimacy of Eastwood City, for most of those interviewed, these still stand secondary to the benefits that the various stakeholders continue to enjoy: the convenience, the opportunities, the lifestyle. Everything else was overshadowed by the "whitened" image of Eastwood City.

\subsection{Normalising Inequality}

The stark inequality present in Eastwood City is the one thing that was rarely complained about by those interviewed. For some, the most attractive part about it is its very exclusivity, founded on aspirational imaginings. This sentiment is not only prevalent among the upper classes but is also echoed by the working class who would typically be among the most excluded. It would seem like inequality has been normalised in the system through layering of exclusive practices. 
Eastwood City, like other urban enclaves, exhibits exclusivity in multiple levels by differentiating itself from its surroundings (Agnotti, 2013). The most obvious is physical isolation, with high-rise buildings forming an enclosure, secured access points, and obvious change in environs. Once inside Eastwood City, a curious combination of an international business district and a western-themed architecture can be immediately observed. There is little to connect the place to its local context; on the contrary, much effort has been made to displace Eastwood City and locate it in a fantasy world of global convergence, with the physical design just as one representation of this. Because much of the employment offered by Eastwood City is from the BPO industry, this creates a community that is highly tied to global processes, creating in itself a global identity (Kleibert \& Kippers, 2015: 10), and setting itself as temporally apart from the outside (Michel, 2010).

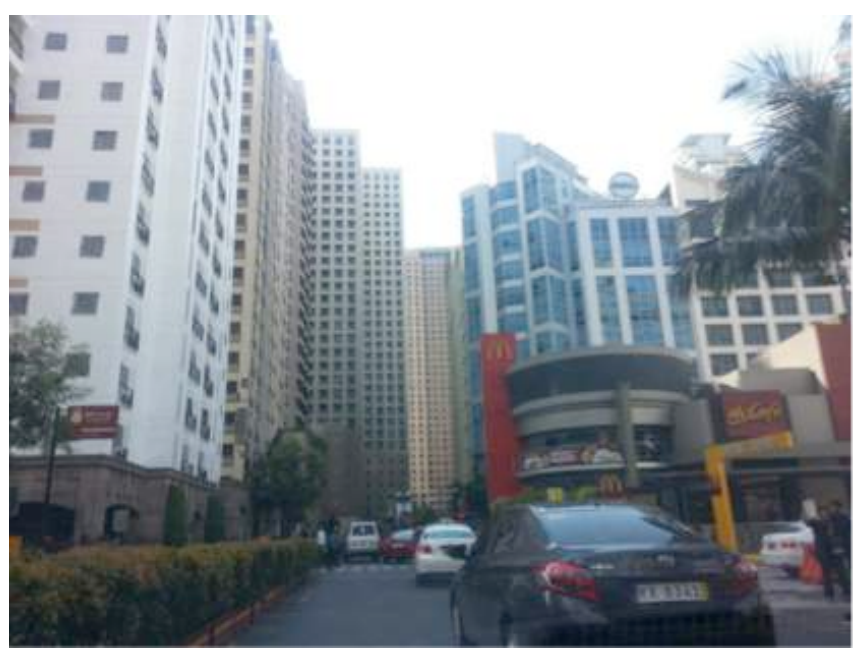

Figure 4 Towers enclosing Eastwood City, source: author, July 2016

However, unlike in mono-use enclaves, this mixed-use characteristic creates a sense of conditional openness to the enclosure (Agnotti, 2013: 115). It grants access to the development to different users, yet segregates the space into layers of exclusivity. This can be observed by how different classes are spread out inside the PUD in unofficially designated areas, with the most dispossessed finding their space in the margins.

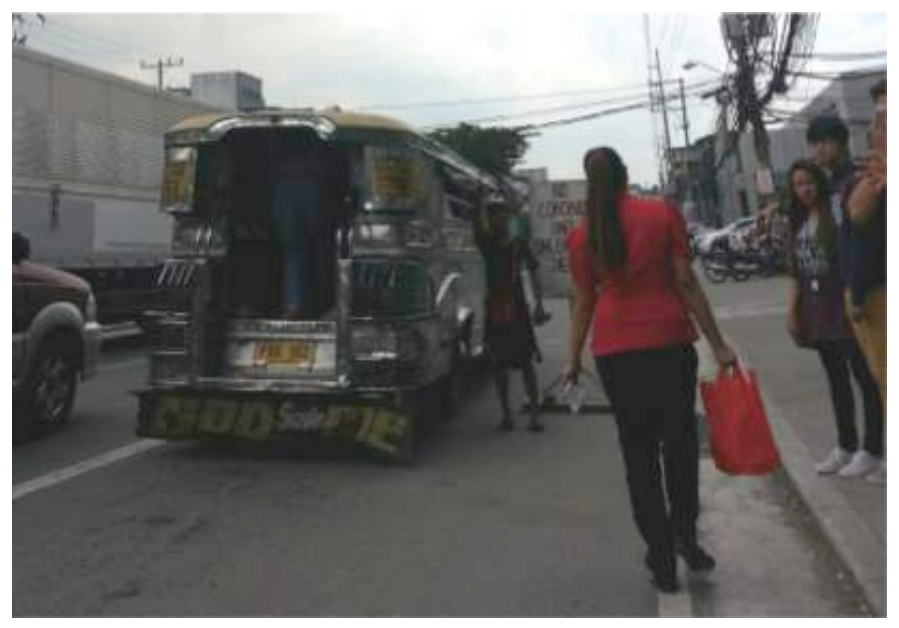

Figure 5 Jeepney waiting for passengers at No Loading and Unloading Zone, source: author, July 2016 
At every entry point, one can find vibrant and often informal activities that cater to Eastwood City: transient food vendors lining, jeepneys stopping at "no loading/unloading" zones, "colorum" [unlicensed] public shuttles waiting surreptitiously for passengers. These alternative spaces can be found not only in the boundary, but also within the perimeter of the development: the common presence of technically illegal condo-sharing, a dormitorytype business/living arrangement to cut down costs of rent; lunch vendors disguising their wares and bring it into offices and shops; deals with the security crew allows for a blind eye in imposing restrictions. When asked about these exhibitions of informality, an interviewee replied, "If we don't do anything [about our situation], then nothing will happen." (Store cashier, interview, 26 July 2016)

These instances show that within and around the development are further states of exception, tolerated because they are used to address the needs of those the developer does not provide for, and existing as part of the deregulated system that persists in the PUD. These emphasize that space continuously changes due to the manifestations of these relations in the margins. However, while these can be seen as exhibitions of power, these can also further embed practices of exclusion into the system, as they remain in the peripheries of acceptability. How can there be a move towards equality when inequality has been normalised as a truth?

Barangay Bagumbayay, literally at the periphery and separated from the development, exhibits a significantly different case from the aforementioned examples of power at the margins. Because Eastwood City is located within the territory of Barangay Bagumbayan, it is actually under the jurisdiction of the barangay and must answer to their requirements. This status has given the barangay bargaining power despite being a poor community. To build, occupy, and operate, Eastwood City must coordinate and claim clearances with the barangay.

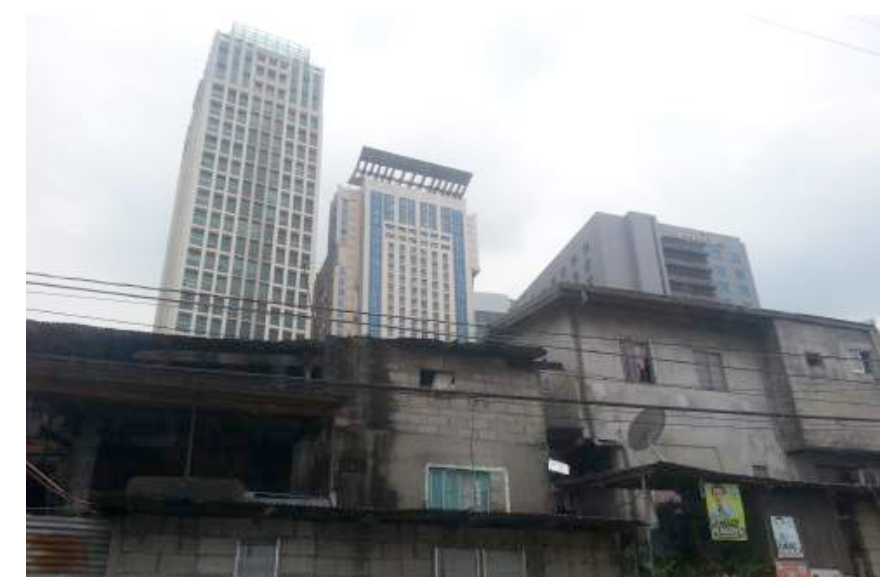

Figure 6 Barangay Bagumbayan with Eastwood City towers behind, source: author, July 2016

The imbued power of the barangay has given them a sense of control over their surroundings. They can deny or allow access, demand reparations and make concessions. While displacement is an ever-present concern, there is a sense of protection. The experience of Barangay Bagumbayan is an unexpected counterpoint to the dispossession of other sectors in Eastwood City. The power of the barangay does not come from the margins but from an acknowledged place: policy. Thus, in the effort to open various narratives and normalise equality in these PUDs, these spaces of exceptions, a turn to improvement of policy regarding these developments may be a step in the right direction. 


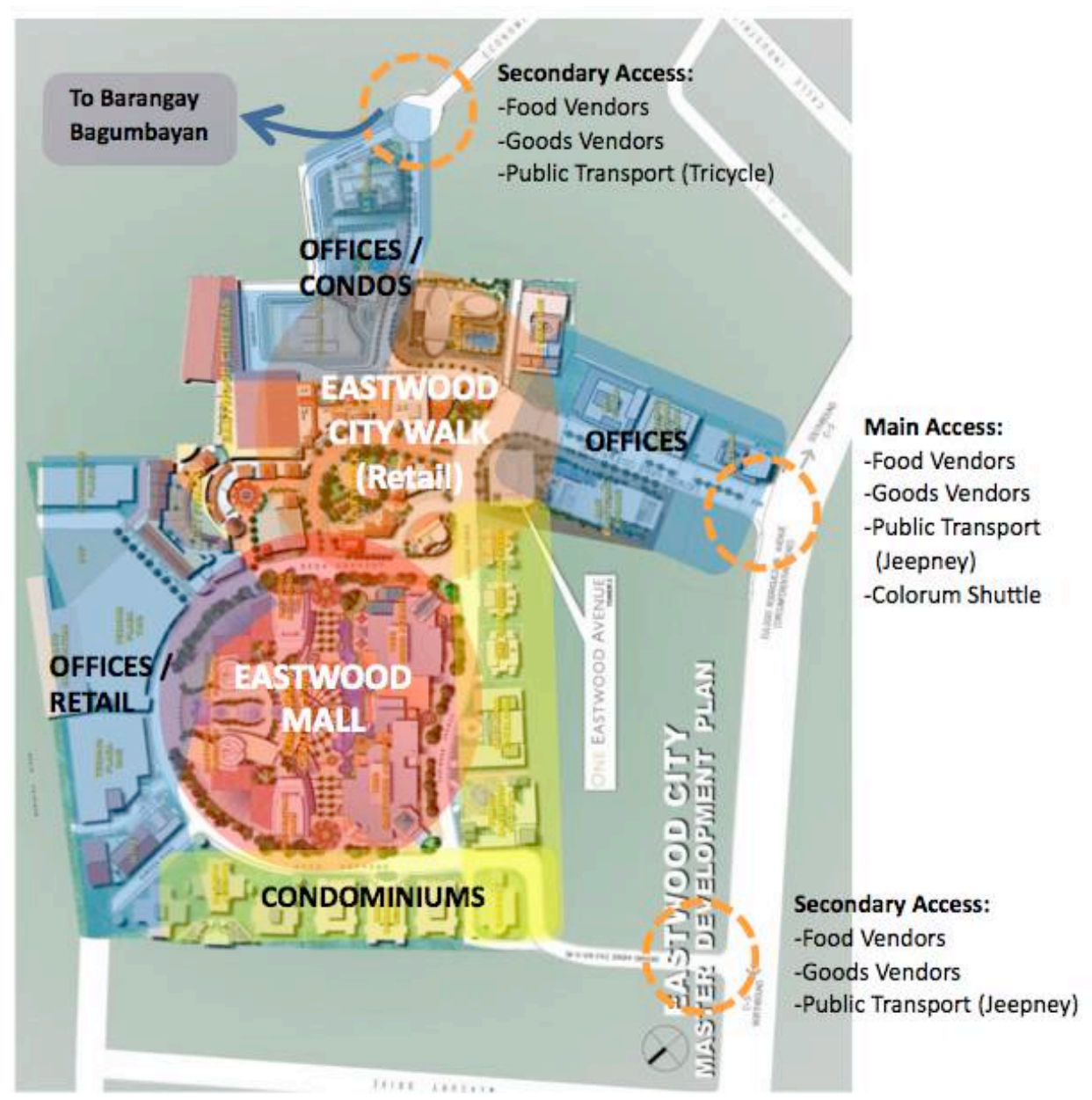

Figure 7 Eastwood City Master Development Plan (with overlay of uses/activities), source of base map: One Eastwood Avenue, Megaworld Corporation.

\subsection{Negotiating Planned Unit Developments}

Through the example of Eastwood City, PUDs have been argued as spaces of exception that are shaped through the (in)formal relations of various actors. However, because the power/knowledge of these relations are inherently unequal, so too are the places these shape. This assemblage of relations, however, is not set in stone and is indeed open for reassemblages that can imagine new potentials (McFarlane, 2011: 211). Providing policies, like that in Barangay Bagumbayan, can provide new ways of inclusion.

Flexibility in planning processes does have numerous advantages such as allowing for spaces to be more responsive to changing contexts and leading to better designed environments. It is for these reasons that the concept of PUDs and other similar spaces of exception were initially formed (Herrle \& Fokdal, 2011: 12). While these developments indeed have a tendency to be abused, these can also facilitate more inclusiveness in the planning process due to its openness for negotiations. However, leaving it as status quo tends to create spaces that focus primarily on private interests (Mandelker, 2008). Thus, there is a need to achieve a balance between regulation and flexibility towards "a model that accepts unpredictability and informality without surrender to the ravages of market-led ideology... 
that does not kill the vitality, productivity and adaptability that sustains lives" (Dovey, 2012: 365).

One possible approach is to operationalise the concept of PUDs as a public planning tool, wherein various stakeholders outside the state-developer relationship are treated as active participants taken into consideration from the outset instead of mere passive consumers of the delivered product (Sager, 2011: 181). International examples exist, for instance the ZACs of France and UOs of Brazil, but due to stark differences on how these places are manifested in the Philippine context, care should be taken in transferring ideas from varying realities (Patel, 2014), such as placing too much trust on how the state can advocate the needs of the community during the process and ensuring that the benefits acquired from these developments are used for public services. However, institutionalizing this continuous negotiation processes among different actors would at least "[enable] people as citizens with political roles, rights, and agendas" (Sager 2011:181).

In trying to answer how these developments should be negotiated, this study does not attempt to create definitive recommendations. Rather, it exposes factors and opens up possibilities on how PUDs can actually be negotiated to enable inclusiveness: with the continuous sharing of power throughout its lifespan. While this is difficult to achieve because power's demarcations are ingrained in the system, recognizing and operationalising PUDs as spaces of exception can instigate this shift, promote the long-lasting legitimacy of the PUD and, ideally, move towards truly inclusive and sustainable societies.

\section{Conclusion}

The findings of this study uncover Eastwood City as a story of potential. Eastwood City is presented as a space of exception whose mutability is negotiated by the power/knowledge relations. Its need for flexibility from rigid land use plans is facilitated through a deregulated system of mutually beneficial (in)formal negotiations between state-developer. This space is legitimised through narratives of sustainability, yet normalizes unsustainable practices of over-densification and exclusion. While the public seems satisfied with Eastwood City due to these narratives and even appears to appreciate the exclusivity it espouses, their dispossession is evident and exhibits power in the margins of the development. Barangay Bagumbayan, the poor community along the edges of the development, acts as a counterpoint whose recognized status over Eastwood City as part of its jurisdiction has given the community power through policy.

This brings the discussion to how Planned Unit Developments should be negotiated through uncovering the processes that may lead to more inclusiveness in the continuous (re)shaping of the PUD. Based on the experience of Eastwood City, it is in operationalising PUD as a planning tool through legitimising the act of negotiation and sharing this power among all stakeholders, not only during the creation but also throughout the lifespan of the PUD, that can ideally lead to more inclusive and sustainable enclaves.

While this study can be further strengthened by exploring more manifestations of PUDs in different cities of Metro Manila (as well as in other developing cities), Eastwood City as one of the first and most established can reveal processes that may have similarities to the experience of other PUDs and act as a starting point in understanding them. This can lead to more in-depth analysis of PUDs, comparing how they are implemented in various contexts, 
observing their changes over time, or networking these within the urban systems of the megacity. Furthermore, these findings can be a resource for a more inclusive approach on planning for these spaces of exception.

\section{References}

Agamben, G. (2005). State of exception. Chicago: University of Chicago Press.

Aquino, R. (2015). Cities within a city: the rise of Manila's new urban townships. [online] Property Report. Available at: http://www.property-report.com/cities-within-a-citythe-rise-of-manilas-new-urban-townships/ [Accessed 6 Jul. 2016].

Burchell, R. (1973). Frontiers of planned unit development: a synthesis of expert opinion. New Brunswick, N.J.: Center for Urban Policy Research.

Choi, N. (2014). Metro Manila through the gentrification lens: Disparities in urban planning and displacement risks. Urban Studies, 53(3), pp.577592.DOI:10.1177/0042098014543032

Committee on Public Regulation of Land Use. (1972). PLANNED UNIT DEVELOPMENTS AND FLOATING ZONES. Real Property, Probate and Trust Journal, 7(1), 61-67.

Connell, J. (1999). Beyond Manila: walls, malls, and private spaces. Environ. Plann. A, 31(3), pp.417-439. DOI: 10.1068/a310417

Council for New Urbanism (CNU). (2015). What is New Urbanism?. [online] Available at: https://www.cnu.org/resources/what-new-urbanism [Accessed 2 Jul. 2016].

Dempsey N., \& Jenks, M. (2010). The Future of the Compact City. Built Environment (1978), 36(1), 116-121. Retrieved from http://www.jstor.org/stable/23289987

Dovey, K. (2012). Informal urbanism and complex adaptive assemblage. International Development Planning Review, 34(4), pp.349-368. DOI: 10.3828/idpr.2012.23

Endriga, D. (2004). The language of environmental planning in the Philippines. Quezon City, Philippines: School of Urban and Regional Planning, University of the Philippines and UP Planning and Development Research Foundation.

Foucault, M.(1998). Aesthetics, method, and epistemology. New York: New Press.

Franklin, B. and Tait, M. (2002). Constructing an Image: The Urban Village Concept in the UK. Planning Theory, 1(3), pp.250-272. DOI: 10.1177/147309520200100304

Garrido, M. (2013). The Sense of Place behind Segregating Practices: An Ethnographic Approach to the Symbolic Partitioning of Metro Manila. Social Forces, 91(4), pp.1343-1362. DOI: 10.1093/sf/sot039

Garrido, M. (2012). The Ideology of the Dual City: The Modernist Ethic in the Corporate Development of Makati City, Metro Manila. International Journal Urban Regeneration Research, 37(1), pp.165-185. DOI: 10.1111/j.1468-2427.2011.01100.x

Genis, s. (2007). Producing Elite Localities: The Rise of Gated Communities in Istanbul. CURS, 44(4), pp.771-798.DOI: 10.1080/00420980601185684 
Grant, J. and Mittelsteadt, L. (2004). Types of gated communities. Environment and Planning B: Planning and Design, 31(6), pp.913-930. DOI:10.1068/b3165

Herrle, P. and Fokdal, J. (2011). Beyond the Urban Informality Discourse: Negotiating Power, Legitimacy and Resources. Geographische Zeitschrift, 99(1), 3-15.

Hofstad, Hege, Compact city development: High ideals and emerging practices, Refereed article No. 49, October, 2012, European Journal of Spatial Development. (Citation as instructed)

Housing and Land Use Regulatory Board, (2014). CLUP Guidebook: A Guide to Comprehensive Land Use Plan Preparation.

lossifova, D. (2014). Borderland urbanism: seeing between enclaves. Urban Geography, 36(1), pp.90-108. DOI: 10.1080/02723638.2014.961365

Jenks, M and Jones, C (2010). Chapter 1: Issues and Concepts. In: Jenks, M and Jones, C (eds.) Dimensions of the Sustainable City. London: Springer.

Jensen, J, Christensen, T and Gram-Hanssen, K (2011). Sustainable Urban Development Compact Cities or Consumer Practices? Danish Journal of Geoinformatics and Land Management 46(1), 50-64.

Johnson, L. (2010). Master Planned Estates: Pariah or Panacea?. Urban Policy and Research, 28(4), pp.375-390. DOI: 10.1080/08111146.2010.532475

Kelly, P. (2003). Urbanization and the Politics of Land in the Manila Region. The Annals of the American Academy of Political and Social Science, 590(1), pp.170-187. DOI: $10.1177 / 0002716203256729$

Kleibert, J. and Kippers, L. (2015). Living the good life? The rise of urban mixed-use enclaves in Metro Manila. Urban Geography, 37(3), pp.373-395. DOI:

10.1080/02723638.2015.1082799

Koch, F. (2015). The Rules of the Game and How to Change Them: Urban Planning Between Formal and Informal Practices. A Colombian Case Study. International Planning Studies, 20(4), pp.407-423.DOI: 10.1080/13563475.2015.1068685

MacLeod, G. and Ward, K. (2002). Spaces of Utopia and Dystopia: Landscaping the Contemporary City. Geografiska Annaler, Series B: Human Geography, 84(3\&4), pp.153-170. DOI: 10.1111/1468-0467.00121

MacLeod, G., Raco, M. and Ward, K. (2003). Introduction. CURS, 40(9), pp.1655-1671.DOI: $10.1080 / 0042098032000106546$

Mandelker, D. (2008). Legislation for Planned Unit Developments and Master-Planned Communities. The Urban Lawyer, 40(3), 419-449.

McFarlane, C. (2011). Assemblage and critical urbanism. City, 15(2), pp.204-224. DOI: 10.1080/13604813.2011.568715

McFarlane, C. (2012). Rethinking Informality: Politics, Crisis, and the City. Planning Theory \& Practice, 13(1), pp.89-108. DOI: 10.1080/14649357.2012.649951 
McGuirk, P. and Dowling, R. (2009). Master-planned residential developments: Beyond iconic spaces of neoliberalism?. Asia Pacific Viewpoint, 50(2), pp.120-134. DOI: 10.1111/j.1467-8373.2009.01388.x

Meshenberg, M. (1976). The administration of flexible zoning techniques. Chicago: American Society of Planning Officials.

Michel, B. (2010). Going Global, Veiling the Poor Global City Imaginaries in Metro Manila. 58(3), pp.383-406.

Mills, S. (2003). Michel Foucault. London: Routledge.

Murphy, P. and Hogan, T. (2012). Discordant order: Manila's neo-patrimonial urbanism. Thesis Eleven, 112(1), pp.10-34.DOI: 10.1177/0725513612450500

Neuman, M. (2005). The Compact City Fallacy. Journal of Planning Education and Research, 25(1), pp.11-26. DOI: 10.1177/0739456x04270466

Ortega, A. (2016). Manila's metropolitan landscape of gentrification: Global urban development, accumulation by dispossession \& neoliberal warfare against informality. Geoforum, 70, pp.35-50. DOI: 10.1016/j.geoforum.2016.02.002

Oxford Business Group. (2015). The Philippines' BPO sector creates jobs and is drawing wealth and investment. [online] Available at: https://www.oxfordbusinessgroup.com/overview/philippines-bpo-sector-createsjobs-and-drawing-wealth-and-investment [Accessed 13 August 2016].

Patel, S. (2014) Is there a 'South' perspective to urban studies? (eds.) The Routledge Handbook on Cities of the Global South. Oxon, Routledge. pp. 37-47.

Porio, E. (2009). Shifting spaces of power in Metro Manila. City, 13(1), pp.110-119. DOI: $10.1080 / 13604810902726301$

Porio, E. (2012). Decentralisation, Power and Networked Governance Practices in Metro Manila. Space and Polity, 16(1), pp.7-27. DOI: 10.1080/13562576.2012.698128

Pow, C. (2014). Urban dystopia and epistemologies of hope. Progress in Human Geography, 39(4), pp.464-485. DOI: 10.1177/0309132514544805

Quezon City Development Council, (2010). Quezon City Comprehensive Development Plan 2010-2016. Quezon City.

Roderos, R. (2013). Reshaping Metro Manila: Gentrification, Displacement, and the Challenge Facing the Urban Capital. ST, 1(2), pp.79-103. DOI: $10.13185 /$ st2013.01204

Roy, A. (2005). Urban Informality: Toward an Epistemology of Planning. Journal of the American Planning Association, 71(2), pp.147-158. DOI: 10.1080/01944360508976689

Roy, A. (2009). Why India Cannot Plan Its Cities: Informality, Insurgence and the Idiom of Urbanization. Planning Theory, 8(1), pp.76-87. DOI: 10.1177/1473095208099299

Sager, T. (2011). Neo-liberal urban planning policies: A literature survey 1990-2010. Progress in Planning, 76(4), pp. 147-199. DOI: 10.1016/j.progress.2011.09.001 
Shatkin, G. (2005). Colonial Capital, Modernist Capital, Global Capital: The Changing Political Symbolism of Urban Space in Metro Manila, the Philippines. Pacific Affairs, 78(4), pp.577-600. DOI: 10.5509/2005784577

Shatkin, G. (2008). The City and the Bottom Line: Urban Megaprojects and the Privatization of Planning in Southeast Asia. Environment and Planning A, 40(2), pp.383-401. DOI: 10.1068/a38439

Sidaway, J. (2007). Enclave space: a new metageography of development?. Area, 39(3), pp.331-339. DOI: 10.1111/j.1475-4762.2007.00757.x

Smyth, H. (2005). Running the Gauntlet: A Compact City within a Doughnut of Decay. In Jenks, M, Burton, E and Williams, K (eds.) The Compact City: A Sustainable Urban Form? London: Spon Press. p. 101-113.

So, F., Mosena, D. and Bangs, F. (1973). Planned unit development ordinances. [Chicago]: [American Society of Planning Officials].

Webster, C., Glasze, G. and Frantz, K. (2002). The Global Spread of Gated Communities. Environment and Planning B: Planning and Design, 29(3), pp.315-320. DOI: $10.1068 / \mathrm{b} 12926$

Yiftachel, O. (2009). Critical theory and 'gray space': Mobilization of the colonized. City, 13(23), pp.246-263. DOI: 10.1080/13604810902982227 